\title{
Safety issue likely to override US export ban
}

Washington

THE United States is expected shortly to waive the provisions of the 1978 Nuclear Non-Proliferation Act and send India urgently-needed spare parts for its troubled American-built light-water reactors at Tarapur, north of Bombay. The State Department believes Congress will approve the shipment on humanitarian grounds, following reports that radiation leakage at the site has reached a hazardous level.

Although India's request for the parts will be a major issue during talks this month between Secretary of State George Shultz and Mrs Indira Gandhi, the Indian Prime Minister, Indian authorities have been trying to play down the problems at Tarapur. The Indian Atomic Energy Commission denies that radiation leakage has reached hazardous levels and the Indian Embassy in Washington refuses to confirm reports that one of the two General Electric reactors has been shut down and that the other is operating at below half power.

US congressional staff dismiss as "hyperbolic" claims in some Indian newspapers that conditions at Tarapur are so dangerous that local villagers have been recruited to work at the plant for only the very brief spells possible before they receive a dangerous lifetime dose of radiation. But staff aides believe that attempts by the Indian Government to stretch out dwindling fuel supplies by using low-quality fuel have resulted in serious contamination of the primary coolant.

The United States and India have been at loggerheads over the Tarapur plant ever since India's " peaceful" nuclear explosion in 1974 and the enactment of the Nuclear Non-Proliferation Act in 1978. The act obliges the United States to cut off enriched-uranium fuel exports until India agrees to place all its nuclear facilities under inspection by the International Atomic Energy Agency (IAEA). President Carter managed by a whisker to persuade Congress to authorize a fuel shipment in 1980, but the Reagan Administration subsequently arranged for the French to take over fuel supplies for Tarapur.

India maintains that its 1963 agreement on cooperation between the two countries at Tarapur ought not to have been suspended as a result of later domestic legislation in the United States. The two governments also disagree about the status of the agreement's original safeguards governing the use of plutonium produced at Tarapur. India argues that the safeguards, currently enforced by IAEA, lapse when the overall agreement expires in 1993. The United States maintains that the safeguards which are already considered defective - should continue to remain in force.

The history of discord surrounding Tarapur will complicate the administration's task of persuading Congress to agree to the shipment of spare parts. The House Foreign Affairs Committee recently rejected a proposal to amend the act so that nuclear components could be exported on health and safety grounds to nations which refused to accept IAEA supervision. Members felt it would be virtually impossible to distinguish between components necessary for health and safety and those needed for general operation of reactors.

Many congressmen are convinced that India misused US heavy water and Canadian uranium in order to achieve the 1974 explosion, and some are expected to argue that India should be forced to solve its Tarapur problems by closing down the plants. Paul Leventhal, president of the Nuclear Control Institute, last week urged this course on Congress, arguing that the United States should not allow itself to be held responsible for the safety of the Indian nuclear programme. He added: "If India cannot operate the plant safely without the embargoed parts, it should either shut the plant down or make the non-proliferation commitments necessary to assure immediate shipment of the plants from the United States."

Even if a majority in Congress rejects this view, shipment of the necessary parts may not take place until the end of the year. If the administration seeks a waiver under the terms of the act, it must allow Congress 60 legislative days to decide whether to give its approval. An easier option would be to persuade a third country, such as Japan, to provide the General Electric-type components. But State Department attempts to prevail on the Japanese are said to have been rebuffed.

\section{US science budget}

\section{Congress acts with 1984 in mind}

\section{Washington}

CONGRESS and the White House appeared last week to be rushing headlong towards confrontation as both the House of Representatives and the Senate approved a 1984 budget plan which will raise domestic spending and reduce defence spending to levels that President Reagan has already described as unacceptable. Under the congressional budget, total spending on federal research and development is expected to fare slightly less well than it would under the White House plan for a 17 per cent increase. But virtually all the reductions would be in defence research, with the civilian share of the science budget showing significant increases.

In the midst of the political confusion surrounding the 1984 budget, a five-year plan to add $\$ 5,000$ million to the budgets of six federal agencies which fund university research was unveiled at a Capitol Hill press conference. The initiative, led by two Missouri senators, Democrat Tom Eagleton and Republican Jack Danforth, was devised with help from the Association of American Universities (AAU) and is to be codified in a University Research Capacity Restoration Act.

Senator Danforth conceded that the initiative was unlikely to have a major impact on the 1984 budget process, which is already at an advanced stage. But he said the act would form a blueprint for congressional action over the coming years designed to revitalize American science and to upgrade the quality of university research. He said co-sponsors of the legislation intended to introduce amendments to the spending of six agencies: the National Institutes of Health (NIH), the National
Aeronautics and Space Administration (NASA), the National Science Foundation (NSF) and the Departments of Energy, Agriculture and Defense.

AAU chairman William Danforth (Senator Danforth's brother) claimed that the senator's initiative was the first attempt by a congressional group to look at the needs of the research universities across the whole range of major spending agencies. The initiative is being supported by a number of prominent Democrats, including Senators Edward Kennedy (Massachusetts) and Daniel Moynihan (New York). Moynihan said last week that there is genuine concern about the United States' dwindling lead in science, and complained that the recent breakthroughs at CERN (the European Organization for Nuclear Research) were the first historic events in experimental physics to take place outside the United States since the 1930s.

A major focus of the initiative is an attempt to upgrade the quality of university equipment and laboratories. The group is planning a series of amendments which would provide federal agencies with extra funds to make outright equipment grants to universities and provide additional funds, on a matching basis, to renew or replace existing laboratories. Annual increases for the Department of Agriculture would be $\$ 70$ million; for Defense $\$ 135$ million; for Energy \$64 million; for NSF $\$ 75$ million and for NASA $\$ 40$ million. The amount for NIH has not been specified.

Funds would also be provided to increase research grants, to raise the number of graduate fellowship awards and to support young investigators beginning research careers.

Peter David 